\title{
Review
}

\section{An update of laboratory diagnosis of Helicobacter pylori in the Kingdom of Saudi Arabia}

\author{
Ali M Somily ${ }^{1,2}$, Muhammad G Morshed ${ }^{3,4}$ \\ ${ }^{1}$ Department of Pathology and laboratory Medicine/Microbiology Unit, College of Medicine, King Khalid and King \\ Saud University Hospital, Riyadh Saudi Arabia \\ ${ }^{2}$ College of Dentistry, King Saud University, Riyadh Saudi Arabia \\ ${ }^{3}$ Zoonotic Diseases and Emerging Pathogens, BCCDC Public Health Microbiology and Reference Laboratory, \\ Provincial Health Services Authority, Vancouver, British Columbia, Canada \\ ${ }^{4}$ Department of Pathology and Laboratory Medicine, University of British Columbia, Vancouver, British Columbia, \\ Canada
}

\begin{abstract}
Helicobacter pylori is a micro-aerophilic, slow-growing, Gram-negative spiral bacterium that colonizes the mucous lining of the human stomach. Infection with this bacterium has been identified as a cause of gastritis, peptic ulcer disease, and gastric mucosa-associated lymphoid tissue lymphoma. Globally, the prevalence of $H$. pylori-related infection is high compared to any other infectious diseases, and the rate of prevalence much higher in developing countries than in developed nations.

This review article aims to describe the trend of $H$. pylori-related works in the Kingdom of Saudi Arabia (KSA) and the use of various laboratory tests for the diagnosis of $H$. pylori-related infections in adults and children.

Therefore, published literature was referenced in the explanation and discussion of the different methods used to diagnose $H$. pylori-related disease, including papers published in the KSA and other Middle Eastern countries. The PubMed (http://www.ncbi.nlm.nih.gov/pubmed?cmd=search) search engine was used extensively.

Culture and histopathology tests have been employed widely to detect this pathogen at the early stage. However, over the years, an array of tests including the rapid urease test, serology, the urea breath test, the fecal antigen test, and molecular testing have been developed to diagnose and better manage $H$. pylori-associated diseases since the discovery of this novel pathogen.
\end{abstract}

Key words: Helicobacter pylori; diagnosis; PCR; culture; Urea breath Test; drug susceptibility.

J Infect Dev Ctries 2015; 9(8):806-814. doi:10.3855/jidc.5842

(Received 03 September 2014 - Accepted 28 April 2015)

Copyright $\left({ }^{\circ} 2015\right.$ Somily et al. This is an open-access article distributed under the Creative Commons Attribution License, which permits unrestricted use, distribution, and reproduction in any medium, provided the original work is properly cited.

\section{Introduction}

Helicobacter pylori is a non-spore-forming Gramnegative bacterium. The cellular morphology may be curved, spiral, or fusiform, typically 0.5 to $1.0 \mu \mathrm{m}$ in width and 2.5 to $5.0 \mu \mathrm{m}$ long. The spiral wavelength may vary with the age, growth conditions, and species identity of the cells [1]. In old cultures or those exposed to air, cells may become coccoid [2].

Although bacteria were seen in stomach tissue (histopathology) a century ago [3], Marshall and Warren (1994) made a phenomenal change in gastroenterology by culturing a novel bacterium from gastric mucosa in 1983 [1], which was a turning point in our understanding of gastrointestinal microbial ecology and disease. This was recognized in 2005 when they won the Nobel Prize in Physiology or Medicine.
The story about how $H$. pylori was discovered is very interesting. The Royal Perth Hospital in Australia where Marshall worked used to discard stomach biopsy culture plates after 48 hours. It was Easter Thursday and plates were supposed to be checked on Saturday; however, technologists did not review them until next Tuesday, which allowed longer incubation and resulted in pure colonies of $H$. pylori [4]. Due to the resemblance of $H$. pylori with Campylobacter in several aspects, including its morphological shape and size, microaerophilic nature, and fastidious character, it was initially named Campylobacter pylorides at the Second International Workshop on Campylobacter Infections held in Brussels, Belgium, in September 1983 [5]. Later, this bacterium was renamed Campylobacter pylori and finally H. pylori based of its flagellar structures, proteins, fatty acid, and genetic compositions [6-7]. Soon after this, all attention turned 
to this novel pathogen. Over last three decades, tremendous progress has been made to understand its biology [8-10], epidemiology [11-12], pathogenicity [13], treatment [14-18], and laboratory diagnosis [1922]. The number of peer-reviewed articles on $H$. pylori is still growing (Figure 1). Although the whole genome sequence was completed in 1999 [23], a great deal of research is still needed to understand the growing concern of the multiple-drug resistance issue. In addition to drug resistance, further studies are also needed to understand the host pathogen interaction, transmission route, and its relationship with other microorganisms and diseases.

The aim of this article is to briefly review the Kingdom of Saudi Arabia (KSA) literature on $H$. pylori and describe the utilization of different diagnostic methods by laboratory workers and allied healthcare workers.

\section{Helicobacter pylori literature in the Kingdom of Saudi Arabia}

Since writing this review, 121 articles have been indexed by PubMed when the terms "Helicobacter pylori and Kingdom of Saudi Arabia" were searched for, and the status has not significantly changed since Abdulaziz A Bin Saeed wrote in his editorial that the Saudi contribution was very minimal [24]. In 2007, he found only 70 articles related to $H$. pylori, where the worldwide contribution was over 26,000 articles globally (Figure 1). He also compared the Saudi contribution with Australia's, which has a similar population size with a lower prevalence rate. Australia published over 500 articles in the same period of time [24]. Most of the studies have been done in universities, research centers, or hospital settings. There are many sero-epidemiological studies that were done in the KSA for both the asymptomatic and symptomatic population since the late 1980s [25-31]. In both asymptomatic and symptomatic populations, the rate of infection in the Saudi population is comparable to that in North America and greatly varies by age groups. A gastritis study was initiated in the KSA in the late 1980s immediately after the discovery of this pathogen. Few studies had been conducted to determine the efficacy of different methods [32-33] for the detection and isolation of $H$. pylori. Since 1980 , a number of studies aimed to understand the pathogenesis of this pathogen as well [34-36]. Al-Khattaf [34] reported the presence of cagA and vacA genes in $100 \%$ of patients with adenocarcinoma. Marie [35] showed that H. pylori strains of vacA s1 and the combinations of s1/m1 were
Figure 1. Number of peer-reviewed publications per year on Helicobacter pylori using PubMed search (key words used were Helicobacter pylori or H. pylori in anywhere in the paper)

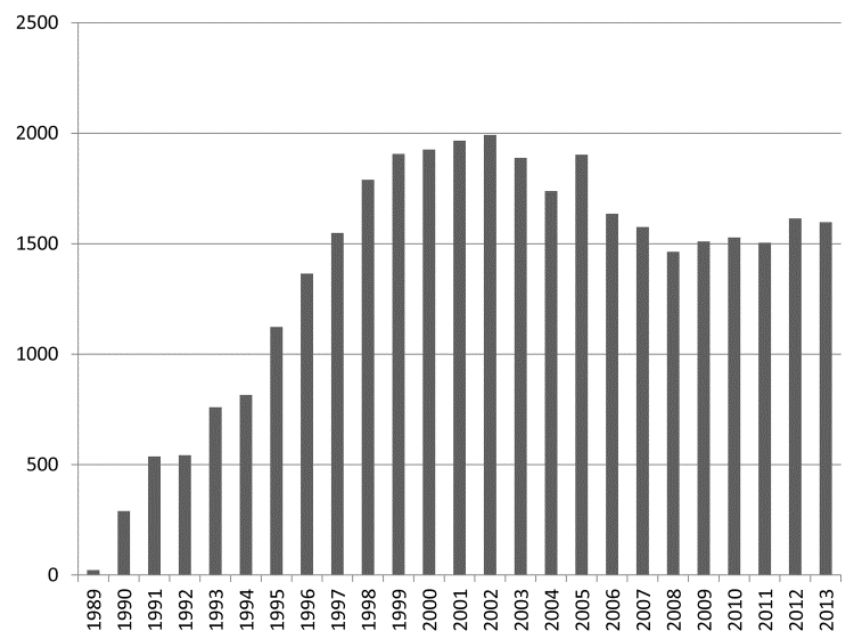

associated with peptic ulceration and the presence of the cagA gene. Momenah and Tayeeb [36] studied the iceA gene. Very few or no studies were done in the areas of cytokines, Lewis antigens, or adhesins to understand more about the pathogenesis of Saudi strains of H. pylori. Recently, King Saud University launched molecular studies on this novel pathogen [35,37]. Momenah and Tayeb (2006) studied iceA genes [38] to understand the relationship between the H. pylori vacA genotype and the risk of peptic ulcer disease. There are several untapped areas in the field of H. pylori and its diseases. Saudi Arabia took the lead among Middle Eastern countries on studying pathogenesis, the gut microbiome, bioinformatics, molecular characterization, and sequencing of the whole genome to understand more about the host pathogen interaction and the transmission route of the H. pylori strains in the Middle East.

\section{Laboratory methods}

There are several laboratory methods that have become available to detect $H$. pylori infection over the last three decades [39]. The tests are divided in two main groups: those that are invasive and others that are not. Invasive methods include histology (microscopy), rapid urease test, culture, and brush cytology; all these tests require endoscopy to obtain biopsy materials. In rare circumstances, biopsy could harm patients, as could brush in an ulcerated area to do cytology in order to diagnose $H$. pylori infection. Non-invasive methods include testing of urine, stool, blood, saliva, and breath samples (Table 1). 
Table 1. Diagnostic tests for Helicobacter pylori

\begin{tabular}{cc}
\hline Invasive & Non-invasive \\
\hline (tissue biopsy required) & Serum antibody (serology) \\
Histology/microscopy & Urea breath test (UBT) \\
Rapid urease test (CLO) & Stool antigen test \\
Culture and susceptibility & Rapid stool antigen test \\
Brush cytology & Saliva/dental plaque PCR \\
Molecular test (PCR) & Urine antibody test \\
\hline
\end{tabular}

\section{Sample collection}

For invasive methods, tissue biopsies from the stomach are considered to be preferred samples. A sterile endoscopic apparatus should be used for each patient, and the patient must adhere to a preendoscopy protocol in order to get the best sample. The patient should not take antibiotics, bismuth substances, and proton pump inhibitors for at least two weeks. The physician should target the ulcerated area of the antrum of the stomach to allow optimal recovery of $H$. pylori. Other methods have been used, including an oro-gastric brush to collect mucosal tissue [40], the string test to obtain gastric mucous [41], and a nasogastric tube to obtain nasogastric juice [42]. None of these methods have been widely used among gastroenterologists.

\section{Sample transport}

Since $H$. pylori is known as a microaerophilic organism sensitive to drying, it has been recommended that rapid transportation using a transport media (Stewart's transport media) is crucial for successful isolation [43]. If transport media is not available, normal saline containing $20 \%$ glucose and glycerol can act as a transport media as well [8]. Bedside sampling would be ideal but is not feasible in most instances.

\section{Invasive methods}

\section{Histology/microscopy}

Since the discovery of $H$. pylori, histopathology (tissue biopsy from the stomach) becomes the number one test of choice of laboratorians. Histopathologists consider this to be the gold standard in the diagnosis H. pylori-related infection in both developed and developing countries. This test also provides additional information such as the degree of inflammation and associated pathology related to metaplasia, lymphoma, mucosa-associated lymphoid tissue (MALT), or cancer. It has now been established that biopsy samples from the affected area of the stomach are optimal for demonstrating $H$. pylori infection. This method may also have a few shortcomings, the major one being patient compliance. Patients should not have any antibiotic at least two weeks prior to their endoscopy and must follow preendoscopic procedures. Accurate test results also depend on many factors such as collection of biopsy from the ulcerated antrum sites of the stomach [44], sample preparation and staining for histopathology slides, and expertise in reading slides and interpreting them accurately [45]. If on-site histopathologists are unavailable, the tissue sample should be blocked in paraffin and then shipped to a site where the expertise is available.

\section{Rapid urease testing}

$H$. pylori is one of the best urease enzymeproducing organisms in the bacterial kingdom. Scientists used that marker to develop urea breath tests that were marketed as CLO tests ("CLO" was used to describe Helicobacter as Campylobacter-like organisms). This has been especially popular in developed countries because of its easy-to-use nature.

This CLO test can be performed at the time of endoscopy because of the desire to know a patient's $H$. pylori status before discharge from the endoscopy suite, and the result can be made available within one hour. To perform this test, a biopsy sample from the stomach is placed into a media containing urea, phenol red ( $\mathrm{pH}$ indicator), buffers, and bacteriostatic agents. If $H$. pylori is present in the sample, it will produce urease enzyme, which will hydrolyze urea to ammonia. As a result, the $\mathrm{pH}$ of the medium will increase and the color will change from yellow to red. Sensitivity and specificity were found to be acceptable (98\% and 97\%, respectively), provided the biopsy sample was collected from an ulcerated antrum site of the stomach [46-47]. False-negative results may occur when very low numbers of $H$. pylori are present or if the bacteria have a patchy distribution [48]. 


\section{Brush cytology}

Brush cytology is not a common method and is rarely used in clinical practice. This test can be considered only in patients with bleeding disorders that make biopsy difficult and risky [49]. The sample obtained from the antrum or body of the stomach can be examined using standard Gram stain techniques or special staining if the results of the Gram stain are inconclusive. Brush cytology has a reported sensitivity of $95 \%$ to $98 \%$ and specificity of $96 \%$ [50].

\section{Bacterial culture and sensitivity testing}

H. pylori is one of the most fastidious and slowgrowing bacteria. Although culture is considered the gold standard, very few laboratories routinely culture H. pylori due to its complex nature, slow growth, and special growth requirements. Routine culture as a diagnostic tool is not recommended. However, in patients in whom standard second-line antimicrobial therapy has failed, culture is essential to determine which antibiotics the organism is sensitive to. $H$. pylori requires $85 \% \mathrm{~N}_{2}, 10 \% \mathrm{CO}_{2}$, and $5 \% \mathrm{O}_{2}$ for its optimal growth. Growth occurs at $34^{\circ} \mathrm{C}$ to $40^{\circ} \mathrm{C}$, with an optimum temperature of $37^{\circ} \mathrm{C}$, and requires three to five days. It can also be grown in a candle jar, although sensitivity is low [22]. Although its natural habitat is the acidic gastric mucosa, $H$. pylori grows best at a neutral PH (7.0), although it will survive brief exposure to $\mathrm{pHs}$ of less than four [51].

H. pylori is inherently resistant to nalidixic acid, trimethoprim, sulfonamides, and vancomycin; those antibacterial agents can be used in culture media to avoid contamination and allow selective isolation. For this reason, $H$. pylori culture facility should be available in teaching hospitals or reference laboratories.

\section{Molecular methods}

Detection and drug susceptibility testing

H. pylori is sensitive to penicillin, ampicillin, cephalothin, kanamycin, gentamicin, rifampin, clarithromycin, tetracycline and metronidazole; however, over the years, resistance to these antibacterial agents has been reported to varying degrees. These variations differ significantly in different regions or countries. Since culturing of this microorganism is difficult, it is often hard to achieve optimal concentrations (McFarland standard 2) do an antibiogram. As a result, traditional drug susceptibility testing is not available in most laboratories, and physicians treat patients with drug regimens known to be effective. The most commonly used anti-H. pylori drugs are macrolides (clarithromycin), amoxicillin, floroquinolones, rifamycin, tetracycline, and metronidazole. Resistance to all of them has become an alarming issue. The most popular drug regimens are combinations of clarithromycin, metronidazole, and a proton pump inhibitor, or amoxicillin, metronidazole, and a proton pump inhibitor [52].

Polymerase chain reaction (PCR) has not been considered to be practical tool for the routine diagnosis of $H$. pylori; however, many laboratories are now moving to this as a result of convenience and efficacy. A few laboratories also use real-time PCR to determine drug resistance against commonly used drugs (clarithromycin, tetracycline, metronidazole) by detecting point mutations (Table 2). PCR has also been found to be useful in detecting the organism when ordinary culture is difficult, as with testing environmental samples such as drinking water [53]. Drug resistance monitoring in communities or regions allow healthcare providers to better define susceptibility patterns and establish optimal treatment regimens [54]. H. pylori is resistant to nalidixic acid, trimethoprim, sulfonamides and vancomycin; however, it is also capable of acquiring resistance to any drug that is overly used, and this has become a major issue in treating patients successfully. The most commonly used drug, metronidazole, showed resistance of $80 \%-90 \%$ in tropical countries, $50 \%$ in European countries, and $80 \%$ in Saudi Arabia [55]. Bakri (2013) [56] found a higher percentage of clarithromycin-resistant genes in Saudi Arabia. These results indicate that physicians should be careful

Table 2. Antibiotic groups and genes involved in point mutation or other genetic changes leading to antimicrobial resistance in Helicobacter pylori

\begin{tabular}{clcc}
\hline Antibiotic group & Antibiotic target & Gene involved \\
\hline Macrolides & Binds to P site on 50S subunit of bacterial ribosome; inhibits protein synthesis & $23 S r r n$ \\
Metronidazole & Inhibits nucleic acid synthesis by disrupting DNA & $r d x A$ \\
Quinolones & Inhibit DNA gyrase (in many Gram-negative bacteria) & $g y r A$ \\
Rifamycins & Affinity for prokaryotic RNA polymerase; inhibits DNA-dependent RNA synthesis & $r p o B$ \\
Amoxicillin & Inhibits peptide crosslinking during PG synthesis & $p b p-1 A$ \\
Tetracycline & Binds to 30S ribosome subunit; inhibits amino-acyl tRNA binding & $16 S$ rrn \\
\hline
\end{tabular}


prescribing metronidazole and clarithromycin for $H$. pylori-related dyspepsia. Megraud (2004) provided an excellent summary on the prevalence of $H$. pylori resistance to antibiotics, its consequences, and the advances in detecting it so that physicians can make informed decisions about treating patients [52].

\section{Non-invasive methods}

Serology

It is now well understood that $H$. pylori requires a longer time than do other bacteria to cause infection. As a result, IgM is virtually absent. However, IgG and IgA are found in the patient's serum and saliva. IgA and $\mathrm{IgG}$ are found in $80 \%$ and over $95 \%$ patients [5759], respectively. Different methods of serological tests such as complement fixation, hemagglutination, immunochromatography, enzyme-linked immunosorbent assay (ELISA)/enzyme immunoassay (EIA), and western blot have been described in the literature [60], and among them, the ELISA/EIA method achieved greater acceptability by laboratorians due to cost, ease of use, and full automation [58-59]. The sensitivity and specificity of ELISA/EIA depends primarily on the nature of the antigen bound to the solid support.

However, in 1999, chemiluminescent-based EIA showed higher sensitivity as well as specificity compared to traditional colorimetric-based ELISA/EIA [61]. Serology showed the highest sensitivity (92\%) compared to histology (82.2\%), rapid urease tests $(55.6 \%)$, and culture $(51.1 \%)$ in a developing country setting [21]. If any laboratory would prefer to use the serological test for clinical use, local validation is needed because if the prevalence rate is low, the positive predictive value (PPV) will be significantly different in the areas where the prevalence rate is very high. The serological test also has an advantage for the group of patients who cannot afford to go off proton pump inhibitors because of their medical conditions. One of the key questions in using the serological test is whether it can predict cure of the infection. Researchers discovered, in 1995, that the IgG titer decreased $50 \%$ between six and nine months after treatment [62]. At present, due to easy access to the urea breath test (UBT), clinicians mostly rely on UBT rather than on serological tests. Serological testing is an excellent tool to rule out infection, and in a rural area where UBT is unavailable, serological testing still could be useful if used diligently. Even in modern settings, serological testing can be done using an algorithmic approach.

\section{Urea breath test (UBT)}

UBT is based on the hydrolysis of urea by $H$. pylori to produce $\mathrm{CO}_{2}$ and ammonia. A labeled carbon isotope $\left({ }^{14} \mathrm{C}\right.$ or $\left.{ }^{13} \mathrm{C}\right)$ is given by mouth; $H$. pylori liberates ${ }^{14} \mathrm{C}$ - or ${ }^{13} \mathrm{C}$-tagged $\mathrm{CO}_{2}$ that can be detected in breath samples by a scintillation counter. The UBT was discovered long before $H$. pylori by Kornberg et al. (1954), who measured ${ }^{14} \mathrm{CO}_{2}$ in cat's breath [63]. Graham et al. (1987) [64] used the same principle to measure ${ }^{13} \mathrm{C}$, followed by Marshall et al. (1988) [65] for ${ }^{14} \mathrm{C}$ for diagnosing $H$. pylori infection in humans.

Both the non-radioactive ${ }^{13} \mathrm{C}$ test and the radioactive ${ }^{14} \mathrm{C}$ test obtained Food and Drug Administration (FDA) approval and are commercially available. Both tests have similar cost and accuracy. Some physicians prefer the ${ }^{13} \mathrm{C}$ test to ${ }^{14} \mathrm{C}$ since it does not use a radioactive isotope. Although the dose of radiation in the ${ }^{14} \mathrm{C}$ test is minimal, the use of ${ }^{14} \mathrm{C}$ should be avoided in children, pregnant women, and possibly women of childbearing age since no longterm data are available on its safety in these groups [66].

A similar method testing blood instead of breath has been developed. ${ }^{13} \mathrm{C}$-labeled bicarbonate can be measured in blood before and one hour after administration. The urea blood test (Ez-HBT) samples were processed using gas isotope ratio mass spectrometry (Metabolic Solutions Inc., Nashua, USA). This test is not as popular as the breath test. This test has a reported sensitivity of $92 \%$ to $100 \%$ and a reported specificity of $96 \%$ to $97 \%$ [67].

Among the non-invasive tests, the UBT is highly accurate and reproducible in both establishing the disease diagnosis and measuring the treatment outcome. The sensitivity and specificity of ${ }^{14} \mathrm{C}$ UBT are approximately $88 \%$ to $95 \%$ and $95 \%$ to $100 \%$, respectively [68]. False-positive and false-negative results are unlikely but may be observed in patients who are not compliant with the direction provided by the laboratory, such as the withdrawal of any proton pump inhibitor, bismuth, or antibiotic two weeks prior to testing [69].

\section{Stool antigen assay}

The stool sample has had a place in the clinical laboratory for centuries. Since H. pylori has to pass through stool, scientists invested ample time to develop a stool test for it. Although there are few reports on successful culture of $H$. pylori in stool [70] or detection of $H$. pylori in stool by PCR [71], none of those procedures have been very successful. $H$. pylori often becomes non-cultivable due to biliary salts and 
other inhibitors [72]. Stool PCR was also challenging due to the inhibitors affecting it [73]. Stool antigen tests have been extensively evaluated and accepted as routine clinical tests in many laboratories where scintillation counters are unavailable or patients are not willing to ingest isotopically labeled urea. These tests can also be used before and after treatment [74], similar to UBTs, which are widely available and require no special setup [75]. A commercially available enzyme immunoassay is the recommended method for the primary diagnosis of $H$. pylori in stool [76]. The accuracy of the test was evaluated in a study involving 270 patients in whom the diagnosis of $H$. pylori was established by endoscopy and UBT [77]. The sensitivity and specificity of the test were $94 \%$ and $86 \%$, respectively. Similar results were found in a comparably designed study involving 272 infected patients (sensitivity 94\%, specificity 92\%) [78]. This test has been extensively evaluated by several groups [79-81].

\section{Rapid stool antigen tests}

The stool antigen described above is performed in a laboratory, which delays diagnosis. A rapid $H$. pylori stool antigen test that can be performed during a clinic visit is available. This method can be helpful in a rural setting where laboratory facilities are not available [82].

\section{Other assays}

Salivary assays

H. pylori has been found in the oral cavity [83], and this organism was found in both saliva and dental plaque detected by PCR [84]. Serology tests were also developed for saliva and found to be very useful for children. However, because of the availability of stool antigen test assays and the reduced sensitivity of saliva $\mathrm{IgG}$, this test lost ground and no laboratories use it.

\section{Urinary assays}

Similar to salivary assays, a urine-based ELISA was also developed [85] because of the difficulties in obtaining samples from children [86]. Due to the higher sensitivity and specificity of chemeluminescent-based serology, ELISA of urine is no longer used for the diagnosis of $H$. pylori infection [61].

\section{Test recommendations}

No recommendation has been made by the Saudi Medical Council based on local data; gastroenterologists and other physicians mostly rely on test recommendations from either European or Western countries. Briefly, diagnosis of H. pylori for adult patients should be made preferably with the UBT or the stool antigen test. Serology can be used in patients who have never been treated for $H$. pylori since this test cannot differentiate between active and past infection. For the relapsing patient, endoscopy followed by histology, culture, and antibiogram should be performed. PCR is becoming a common test in many laboratory settings and could be used as alternate for culture and antibiogram for detection and to determine drug resistance genes for commonly used antimicrobial drugs. It is worthwhile to confirm $H$. pylori eradication at least four to eight weeks following completion of antibiotic therapy because of increased resistance to antibiotic therapy $[14,16,18,68,76]$.

Children differ from adults in all aspects except the etiological agent $H$. pylori. The European Society for Pediatric Gastroenterology, Hepatology, and Nutrition (ESPGHAN) and the North American Society for Pediatric Gastroenterology, Hepatology, and Nutrition (NASPGHAN) developed guidelines that were revised recently [17]. These are meant only for children in Europe and North America, where the prevalence of disease in this population is low. Canada also had similar guidelines [87]. In developing countries and some industrialized countries, H. pylori infection is usually acquired during the first year of life $[14,18]$. For children with persistent or severe upper abdominal symptoms, upper endoscopy with biopsy should be the investigations of choice, and the ${ }^{13} \mathrm{C}$-UBT is recommended as the best non-invasive diagnostic test that has the added advantage of being able rule out non-H. pylori related complications. The stool antigen test has also been recommended, although it is difficult to obtain stool from teenaged children.

Consensus guidelines for the management of $H$. pylori infection need to be established in the Middle East for both adults and children based on local data and clinical and laboratory practices.

\section{References}

1. Marshall BJ, Warren JR (1984) Unidentified curved bacilli in the stomach of patients with gastritis and peptic ulceration. Lancet 1: 1311-1315.

2. Shirai M, Kakada J, Shibata K, Morshed MG, Matsushita T, Nakazawa T (2000) Accumulation of polyphosphate granules 
in Helicobacter pylori cells under anaerobic conditions. J Med Microbiol 49: 513-519.

3. Unge P (2002) Helicobacter pylori treatment in the past and in the 21st century. In Marshall B, editor. Helicobacter Pioneers: First-hand accounts from the scientists who discovered helicobacters, 1892-1982. Victoria: Blackwell Science Asia. 203-213.

4. Marshall BJ, Noble lecture (2005). http://www.nobelprize.org/nobel_prizes/medicine/laureates/2 005/marshall-lecture.html. Accessed Aug 13, 2015

5. Pearson AD; Great Britain Public Health Laboratory Service (1983) Campylobacter II: Proceedings of the Second International Workshop on Campylobacter Infections, Brussels, 6-9 September. Public Health Laboratory Service, London, United Kingdom. Available: http://www.theeuropeanlibrary.org/tel4/record/300008992679 3 ?classification-ddc $=616.3 \% 2 \mathrm{~F} 4014 \&$ view $=$ provenance. Accessed on April 10, 2015

6. Goodwin CS, McCulloch RK, Armstrong JA, Wee SH (1985) Unusual cellular fatty acids and distinctive ultrastructure in a new spiral bacterium (Campylobacter pyloridis) from the human gastric mucosa. J Med Microbiol 19: 257-267.

7. Goodwin CS, Armstrong JA, Chilvers T, Peters M, Collins MD, Sly L, McConnel W, Harper WES (1989) Transfer of Campylobacter pylori and Campylobacter mustelae to Helicobacter gen. nov. as Helicobacter pylori comb. nov. and Helicobacter mustelae comb. nov., respectively. Int J Syst Bacteriol 39: 397-405.

8. Du MQ, Isaacson PG (2000) Recent advances in our understanding of the biology and pathogenesis of gastric mucosa-associated lymphoid tissue (malt) lymphoma. Forum (Genova) 8: 162-173.

9. Shiotani A, Nurgalieva ZZ, Yamaoka Y, Graham DY (2004) Helicobacter pylori. Med Clin North Am 84: 1125-1136.

10. Blaser MJ, Atherton JC (2004) Helicobacter pylori persistence: biology and disease. J Clin Invest 113: 321-333.

11. Ahmad MM, Rahman M, Rumi AK, Islam S, Huq F, Chowdhury MF, Jinnah F, Morshed MG, Hassan MS, Khan AK, Hasan M (1997) Prevalence of Helicobacter pylori inasymptomatic population--a pilot serological study in Bangladesh. J Epidemiol 7: 251-254.

12. Peleteiro B, Bastos A, Ferro A, Lunet N (2014) Prevalence of Helicobacter pylori Infection Worldwide: A Systematic Review of Studies with National Coverage. Dig Dis Sci 59: 1698-1709.

13. Marshall BJ (1991) Virulence and pathogenicity of Helicobacter pylori. J Gastroenterol Hepatol 6: 121-124.

14. Lee SY (2014) Current progress toward eradicating Helicobacter pylori in East Asian countries: differences in the 2013 revised guidelines between China, Japan, and South Korea. World J Gastroenterol 20: 1493-1502.

15. Kate V, Kalayarasan R, Ananthakrishnan N (2013) Sequential therapy versus standard triple-drug therapy for Helicobacter pylori eradication: a systematic review of recent evidence. Drugs 73: 815-824.

16. Dinis-Ribeiro M, Areia M, de Vries AC, Marcos-Pinto R, Monteiro-Soares M, O'Connor A, Pereira C, Pimentel-Nunes P, Correia R, Ensari A, Dumonceau JM, Machado JC, Macedo G, Malfertheiner P, Matysiak-Budnik T, Megraud F, Miki K, O'Morain C, Peek RM, Ponchon T, Ristimaki A, Rembacken B, Carneiro F, Kuipers EJ; European Society of Gastrointestinal Endoscopy; European Helicobacter Study Group; European Society of Pathology; Sociedade Portuguesa de Endoscopia Digestiva (2012) Management of precancerous conditions and lesions in the stomach (MAPS): guideline from the European Society of Gastrointestinal Endoscopy (ESGE), European Helicobacter Study Group (EHSG), European Society of Pathology (ESP), and the Sociedade Portuguesa de Endoscopia Digestiva (SPED). Endoscopy 44: 74-94.

17. Koletzko S, Jones NL, Goodman KJ, Gold B, Rowland M, Cadranel S, Chong S, Colletti RB, Casswall T, Elitsur Y, Guarner J, Kalach N, Madrazo A, Megraud F, Oderda G; $H$. pylori Working Groups of ESPGHAN and NASPGHAN (2011) Evidence-based guidelines from ESPGHAN and NASPGHAN for Helicobacter pylori infection in children. J Pediatr Gastroenterol Nutr 53: 230-243.

18. Asaka M, Kato M, Takahashi S, Fukuda Y, Sugiyama T, Ota H, Uemura N, Murakami K, Satoh K, Sugano K; Japanese Society for Helicobacter Research (2010) Guidelines for the management of Helicobacter pylori infection in Japan: 2009 revised edition. Helicobacter 15: 1-20.

19. McNulty CA, Lehours P, Mégraud F (2011) Diagnosis of Helicobacter pylori Infection. Helicobacter 1: 10-18.

20. Mégraud F, Lehours P (2007) Helicobacter pylori detection and antimicrobial susceptibility testing. Clin Microbiol Rev 20: $280-322$

21. Morshed MG, Jinnah F, Islam MS, Rumi MA, Ahmed S, Ahmed MM, Sadeque M, Chowdhury MF (1997) Evaluation of culture, histological examination, serology and the rapid urease test for diagnosis of Helicobacter pylori in patients with dyspepsia in Bangladesh. Jpn J Med Sci Biol 50: 55-62.

22. Morshed MG, Islam MS, Zinnah F, Rumi MA, Ahmad MM, Huq F (1995) Growth of Helicobacter pylori in candle jar. Lancet 346: 511.

23. Alm RA, Ling LS, Moir DT, King BL, Brown ED, Doig PC, Smith DR, Noonan B, Guild BC, deJonge BL, Carmel G, Tummino PJ, Caruso A, Uria-Nickelsen M, Mills DM, Ives C, Gibson R, Merberg D, Mills SD, Jiang Q, Taylor DE, Vovis GF, Trust TJ (1999) Genomic-sequence comparison of two unrelated isolates of the human gastric pathogen Helicobacter pylori. Nature 397: 176-180. Erratum in Nature 25: 719 .

24. BinSaeed AA (2009) Glimpse of the Epidemiological Research on Helicobacter pylori in Saudi Arabia. Saudi J Gastroenterol 15: 85.

25. Rashed RS, Ayoola EA, Mofleh IA, Chowdhury MN, Mahmood K, Faleh FZ (1992) Helicobacter pylori and dyspepsia in an Arab population. Trop Geogr Med 44: 304307.

26. Abdullah AM, Gad el Rab MO, al Ayed I, Kambal AM, al Sohaibani M, al Mazyad AL (1997) Helicobacter pylori infection in children in Saudi Arabia. Trop Gastroenterol 18: 63-65.

27. Al-Knawy BA, Ahmed ME, Mirdad S, ElMekki A, AlAmmari O (2000) Intrafamilial clustering of Helicobacter pylori infection in Saudi Arabia. Can J Gastroenterol 14: 772774.

28. Ayoola AE, Ageely HM, Gadour MO, Pathak VP (2004) Prevalence of Helicobacter pylori infection among patients with dyspepsia in South-Western Saudi Arabia. Saudi Med J 25: 1433-1438.

29. Marie MA (2008) Seroprevalence of Helicobacter pylori Infection in Large Series of Patients in an Urban Area of Saudi Arabia. Korean J Gastroenterol 52: 226-229. 
30. Al Faleh FZ, Ali S, Aljebreen AM, Alhammad E, Abdo AA (2010) Seroprevalence rates of Helicobacter pylori and viral hepatitis A among adolescents in three regions of the Kingdom of Saudi Arabia: is there any correlation? Helicobacter 15: 532-537.

31. Novis BH, Gabay G, Naftali T (1998) Helicobacter pylori: the Middle East scenario. Yale J Biol Med 71: 135-141.

32. Mohamed AE, al Karawi A, al Jumah A, Ahmed AM, Sharig S, Yasawy MI, Osaba O (1994) Helicobacter pylori: incidence and comparison of three diagnostic methods in 196 Saudi patients with dyspepsia. Hepatogastroenterology 41: 48-50.

33. Chowdhury MN, al-Hedai-Thy SS, Mofleh IA, Ayoola EA, Rashed RS (1991) Use of selective and non-selective media for the isolation of Helicobacter pylori. Trop Gastroenterol 12: 73-76.

34. Al-Khattaf AS (2012) Helicobacter pylori virulence markers in gastroduodenal disorders. Detection of cytotoxinassociated gene A and vacuolating cytotoxin-associated gene A genes in Saudi patients. Saudi Med J 33: 716-721.

35. Marie MA (2012) Relationship between Helicobacter pylori virulence genes and clinical outcomes in Saudi patients. J Korean Med Sci 27: 190-193.

36. Momenah AM, Tayeb MT (2007) Helicobacter pylori cagA and iceA genotypes status and risk of peptic ulcer in Saudi patients. Saudi Med J 28: 382-385.

37. Melake NA, Shaker GH, Salama MA (2012) Incidence of Helicobacter pylori infection and their clarithromycinresistant strains in otitis media with effusion regarding phenotypic and genotypic studies. Saudi Pharm J 20: 345353.

38. Momenah AM, Tayeb MT (2006) Relationship between Helicobacter pylori vacA genotypes status and risk of peptic ulcer in Saudi patients. Saudi Med J 27: 804-807.

39. Ashton-Key M, Diss TC, Isaacson PG (1996) Detection of Helicobacter pylori in gastric biopsy and resection specimens. J Clin Pathol 49: 107-111.

40. Graham DY, Kudo M, Reddy R, Opekun AR (2005) Practical rapid, minimally invasive, reliable nonendoscopic method to obtain Helicobacter pylori for culture. Helicobacter 10: 1-3.

41. Perez-Trallero E, Montes M, Larrañaga M, Arenas JI (1999) How long for the routine Helicobacter pylori antimicrobial susceptibility testing? The usefulness of the string test to obtain Helicobacter for culture. Am J Gastroenterol 94: 30753076.

42. Westblom TU, Phadnis S, Yang P, Czinn SJ (1993) Diagnosis of Helicobacter pylori infection by means of a polymerase chain reaction assay for gastric juice aspirates. Clin Infect Dis 16: 367-371.

43. Meunier O, Walter P, Chamouard P, Piemont $\mathrm{Y}$ and Monteil $\mathrm{H}$ (1997) Isolation of elicobacter pylori: necessity of control of transport conditions. Pathol Biol (Paris) 45: 82-85.

44. Genta RM, Graham DY (1994) Comparison of biopsy sites for the histopathologic diagnosis of Helicobacter pylori: a topographic study of $H$. pylori density and distribution. Gastrointest Endosc 40: 342-345.

45. Faigel DO, Childs M, Furth EE, Alavi A, Metz DC (1996) New noninvasive tests for Helicobacter pylori gastritis. Comparison with tissue-based gold standard. Dig Dis Sci 41: 740-748.

46. Laine L, Lewin D, Naritoku W, Estrada R, Cohen H (1996) Prospective comparison of commercially available rapid urease tests for the diagnosis of Helicobacter pylori. Gastrointest Endosc 44: 523-526.

47. Nishikawa K, Sugiyama T, Kato M, Ishizuka J, Kagaya H, Hokari K, Asaka M (2000) A prospective evaluation of new rapid urease tests before and after eradication treatment of Helicobacter pylori, in comparison with histology, culture and ${ }^{13} \mathrm{C}$-urea breath test. Gastrointest Endosc 51: 164-168.

48. Seo JH, Youn HS, Park JJ, Yeom JS, Park JS, Jun JS, Lim JY, Park CH, Woo HO, Ko GH, Baik SC, Lee WK, Cho MJ, Rhee KH (2013) Influencing Factors to Results of the Urease Test: Age, Sampling Site, Histopathologic Findings, and Density of Helicobacter pylori. Pediatr Gastroenterol Hepatol Nutr 16: 34-40.

49. Narváez Rodríguez I, Saez de Santamaría J, Alcalde Rubio MM, Pascasio Acevedo JM, Pabón Jaén M, Campos de Orellana AM, Soria Monge A (1995) Cytologic brushing as a simple and rapid method in the diagnosis of Helicobacter pylori infection. Acta Cytol 39: 916-919.

50. Mostaghni AA, Afarid M, Eghbali S, Kumar P (2008) Evaluation of brushing cytology in the diagnosis of Helicobacter pylori gastritis. Acta Cytol 52: 597-601.

51. Stingl K, Altendorf K, and Bakker EP (2002) Acid survival of Helicobacter pylori: how does urease activity trigger cytoplasmic $\mathrm{pH}$ homeostasis? Trends Microbiol 10: 70-74.

52. Mégraud F (2004) H. pylori antibiotic resistance: prevalence, importance, and advances in testing. Gut 53: 1374-1384.

53. Nayak AK, Rose JB (2007) Detection of Helicobacter pylori in sewage and water using a new quantitative PCR method with SYBR green. J Appl Microbiol 103: 1931-1941.

54. Mégraud F, Lehours P (2007) Helicobacter pylori detection and antimicrobial susceptibility testing. Clin Microbiol Rev 20: $280-322$.

55. Eltahawy AT (2002) Prevalence of primary Helicobacter pylori resistance to several antimicrobials in a Saudi Teaching Hospital. Med Princ Pract 11: 65-68.

56. Bakri MM (2013) Prevalence of Helicobacter pylori infection and the incidence of ure A and clarithromycin resistance gene 23S rRNA genotypes status in Saudi Arabia. Saudi J Biol Sci 20: 75-78.

57. Alemohammad MM, Foley TJ, Cohen H (1993) Detection of immunoglobulin $\mathrm{G}$ antibodies to Helicobacter pylori in urine by an enzyme immunoassay method. J Clin Microbiol 31: 2174-2177.

58. Laheij RJ, Straatman H, Jansen JB, Verbeek AL (1998) Evaluation of commercially available Helicobacter pylori serology kits: a review. J Clin Microbiol 36: 2803-2809.

59. Vaira D, Holton J, Menegatti M, Landi F, Ricci C, Ali A, Gatta L, Farinelli S, Acciardi C, Massardi B, Miglioli M; Italian Helicobacter pylori Study Group (1998) Blood tests in the management of Helicobacter pylori infection. Gut 43: S39-S46.

60. Talley NJ, Newell DG, Ormand JE, Carpenter HA, Wilson WR, Zinsmeister AR, Perez-Perez GI, Blaser MJ (1991) Serodiagnosis of Helicobacter pylori: comparison of enzymelinked immunosorbent assays. J Clin Microbiol 29: 16351639.

61. van Der Ende A, van Der Hulst RW, Roorda P, Tytgat GN, Dankert J (1999) Evaluation of three commercial serological tests with different methodologies to assess Helicobacter pylori infection. J Clin Microbiol 37: 4150-4152.

62. Kosunen TU (1995) Antibody titres in Helicobacter pylori infection: implications in the follow-up of antimicrobial therapy. Ann Med 27: 605-607. 
63. Kornberg HL, Davies RE, Wood DR (1954) The activity and function of gastric urease in the cat. Biochem J 56: 363-372.

64. Graham DY, Klein PD, Evans DJ Jr, Evans DG, Alpert LC, Opekun AR, Boutton TW (1987) Campylobacter pylori detected noninvasively by the ${ }^{13} \mathrm{C}$-urea breath test. Lancet 1 : 1174-1177.

65. Marshall BJ, Surveyor I (1988) Carbon-14 urea breath test for the diagnosis of Campylobacter pylori associated gastritis. J Nucl Med 29: 11-16.

66. Graham DY, Klein PD (2000) Accurate Diagnosis of Helicobacter pylori: ${ }^{13} \mathrm{C}$-Urea Breath Test. Gastroenterol Clin North Am 29: 885-893.

67. Ahmed F, Murthy UK, Chey WD, Toskes PP, Wagner DA (2005) Evaluation of the Ez-HBT Helicobacter blood test to establish Helicobacter pylori eradication. Aliment Pharmacol Ther 22: 875-880.

68. Howden CW, Hunt RH (1998) Guidelines for the management of Helicobacter pylori infection. Ad Hoc Committee on Practice Parameters of the American College of Gastroenterology. Am J Gastroenterol 93: 2330-2338.

69. Gatta L, Vakil N, Ricci C, Osborn JF, Tampieri A, Perna F, Miglioli M, Vaira D (2004) Effect of proton pump inhibitors and antacid therapy on ${ }^{13} \mathrm{C}$ urea breath tests and stool test for Helicobacter pylori infection. Am J Gastroenterol 99: 823829.

70. Falsafi T, Valizadeh N, Najafi M, Ehsani A, Khani A, Landarani Z, Falahi Z (2007) Culture of Helicobacter pylori from stool samples in children. Can J Microbiol 53: 411-416.

71. Falsafi T, Favaedi R, Mahjoub F, Najafi M (2009) Application of stool-PCR test for diagnosis of Helicobacter pylori infection in children. World J Gastroenterol 15: 484488.

72. Hänninen ML (1991) Sensitivity of Helicobacter pylori to different bile salts. Eur J Clin Microbiol Infect Dis 10: 515518.

73. van Zwet AA, Thijs JC, Kooistra-Smid AM, Schirm J, Snijder JA (1993) Sensitivity of culture compared with that of polymerase chain reaction for detection of Helicobacter pylori from antral biopsy samples. J Clin Microbiol 31: 19181920.

74. Vaira D, Malfertheiner P, Mégraud F, Axon AT, Deltenre M, Hirschl AM, Gasbarrini G, O'Morain C, Garcia JM, Quina M, Tytgat GN (1999) Diagnosis of Helicobacter pylori infection with a new non-invasive antigen-based assay. HpSA European study group. Lancet 354: 30-33.

75. Braden B, Teuber G, Dietrich CF, Caspary WF, Lembcke B (2000) Comparison of new faecal antigen test with (13) Curea breath test for detecting Helicobacter pylori infection and monitoring eradication treatment: prospective clinical evaluation. BMJ 320: 148.

76. Chey WD, Wong BC; Practice Parameters Committee of the American College of Gastroenterology (2007) American College of Gastroenterology guideline on the management of Helicobacter pylori infection.. Am J Gastroenterol 102: 18081825 .

77. Trevisani L, Sartori S, Galvani F, Rossi MR, Ruina M, Chiamenti C, Caselli M (1999) Evaluation of a new enzyme immunoassay for detecting Helicobacter pylori in feces: a prospective pilot study. Am J Gastroenterol 94: 1830-1833.

78. Manes G, Balzano A, Iaquinto G, Ricci C, Piccirillo MM, Giardullo N, Todisco A, Lioniello M, Vaira D (2001) Accuracy of stool antigen test in posteradication assessment of Helicobacter pylori infection. Dig Dis Sci 46: 2440-2444.
79. Vaira D, Vakil N, Menegatti M, van't Hoff B, Ricci C, Gatta L, Gasbarrini G, Quina M, Pajares Garcia JM, van Der Ende A, van Der Hulst R, Anti M, Duarte C, Gisbert JP, Miglioli M, Tytgat G (2002) The stool antigen test for detection of Helicobacter pylori after eradication therapy. Ann Intern Med 136: 280-287.

80. Makristathis A, Pasching E, Schütze K, Wimmer M, Rotter ML, Hirschl AM (1998) Detection of Helicobacter pylori in stool specimens by PCR and antigen enzyme immunoassay. J Clin Microbiol 36: 2772-2774.

81. Gisbert JP, Pajares JM (2004) Stool antigen test for the diagnosis of Helicobacter pylori infection: a systematic review. Helicobacter 9: 347-368.

82. Jekarl DW, An YJ, Lee S, Lee J, Kim Y, Park YJ, Kim TJ, Kim JI, Park SH (2013) Evaluation of a newly developed rapid stool antigen test using an immunochromatographic assay to detect Helicobacter pylori. Jpn J Infect Dis 66: 6064.

83. Al Sayed A, Anand PS, Kamath KP, Patil S, Preethanath RS, Anil S (2014) Oral Cavity as an Extragastric Reservoir of Helicobacter pylori. ISRN Gastroenterol 2014: 261369. Available:

http://www.hindawi.com/journals/isrn/2014/261369/. Accessed April 10, 2015.

84. Anand PS, Kamath KP, Anil S (2014) Role of dental plaque, saliva and periodontal disease in Helicobacter pylori infection. World J Gastroenterol 20: 5639-5653.

85. Demıray Gürbüz E, Gönen C, Bekmen N, Dölek D, Soytürk M, Sağol Ö, Şimşek İ, Yılmaz Ö (2012) The diagnostic accuracy of urine $\operatorname{IgG}$ antibody tests for the detection of Helicobacter pylori infection in Turkish dyspeptic patients. Turk J Gastroenterol 23: 753-758.

86. Okuda M, Kamiya S, Booka M, Kikuchi S, Osaki T, Hiwatani T, Maekawa K, Fukuda Y (2013) Diagnostic accuracy of urine-based kits for detection of Helicobacter pylori antibody in children. Pediatr Int 55: 337-341.

87. Bourke B, Ceponis P, Chiba N, Czinn S, Ferraro R, Fischbach L, Gold B, Hyunh H, Jacobson K, Jones NL, Koletzko S, Lebel S, Moayyedi P, Ridell R, Sherman P, van Zanten S, Beck I, Best L, Boland M, Bursey F, Chaun H, Cooper G, Craig B, Creuzenet C, Critch J, Govender K, Hassall E, Kaplan A, Keelan M, Noad G, Robertson M, Smith L, Stein M, Taylor D, Walters T, Persaud R, Whitaker S, Woodland R; Canadian Helicobacter Study Group (2005) Canadian Helicobacter Study Group Consensus Conference: Update on the approach to Helicobacter pylori infection in children and adolescents-an evidence-based evaluation. Can J Gastroenterol 19: 399-408.

\section{Corresponding author}

Dr. Muhammad G Morshed

Department of Pathology \& Laboratory Medicine

University of British Columbia

655 West 12th Avenue

Vancouver, BC, V5Z 4R4 Canada

Phone: + (604) 707-2622

Fax: + (604) 707-2602

Email: muhammad.morshed@bccdc.ca

Conflict of interests: No conflict of interests is declared. 